American Journal of Environmental Sciences 7 (4): 370-376, 2011

ISSN 1553-345X

(C) 2011 Science Publications

\title{
Environmental Ethics in River Water Management
}

\author{
${ }^{1}$ Ravichandran Moorthy and ${ }^{2}$ Ganesan Jeyabalan \\ ${ }^{1}$ School of History, Politics and Strategy, \\ Faculty of Social Sciences and Humanities, \\ University Kebangsaan Malaysia, 43000 Bangi, Selangor, Malaysia \\ ${ }^{2}$ Ministry of Science, Technology and Innovation, Malaysia
}

\begin{abstract}
Problem statement: Environmental ethics concerns human beings' ethical relationship with the natural environment. The fundamental question regarding environmental ethics is basically-what moral obligations do we have concerning the natural environment? The main objective of this study is to examine the extent environmental ethics manifest in river management. The study employs the case study of Malaysia's Gombak River-one of the most polluted urban rivers that run through some heavily inhabited urban areas. The study examines how the Department of Environment (DOE), Drainage and Irrigation Department (DID) and Selayang Municipal Council (MPS) manage the problem of pollution in the Gombak River. Approach: This study uses both quantitative and qualitative analysis. A quantitative approach is employed to assess the water quality in several points along Gombak River. This is done by way of series of scientific testing to determine the level of pollution in the river. Secondly, a qualitative approach is applied on the data gathered through expert interviews on inter-agency coordination efforts to manage pollution problems. Results: The study firstly shows that the Gombak River is considerably polluted, with higher levels of pollution in upstream as compared to the downstream. The second finding suggests that notwithstanding several legislations that are already in place, there is sluggishness in the enforcement of pollution mitigation efforts as a result of ineffective inter-agency communication and coordination. Conclusion: The lack of concerted and coordinated efforts between river management agencies have been cited as one of the main factors contributing to river pollution. Therefore, the agencies concerned should embark on cohesive measures to ensure the rivers are managed well and its water quality controlled. This requires for a structured coordination mechanism between agencies to be put in place and such mechanism can be emulated in the management of other rivers in the country.
\end{abstract}

Key words: Environmental ethics, river water management, inter-agency coordination, gombak river

\section{INTRODUCTION}

Notwithstanding the rising concerns in environmental issues in almost every aspect of human endeavour, the ethical facet of environmental concerns has not been very well expressed in policy formulation. In dealing with environmental issues, there is an inclination among policy makers and implementers to move directly from environmental issues to environmental actions-narrowing down to mitigation initiatives to address these issues. However, such an approach only allows for the prognosis of the immediately symptoms and does not necessarily allow for a long term solution. Some scholars have claimed that mitigation actions should first reflect on the goals, the extent and the ethical justification in the formulation of environmental policies. Policy makers should ask some fundamental ethical questions to provide the necessarily clarity of thought on the objectives the policy intend to achieve. "Should we only protect the environment to the extent that we have an interest in it? What is it that is worth protecting: species, individuals, ecosystems? What does the notion of sustainability means?" (Ten Have, 2006).Asking these questions is necessary as it enables the policy maker to reflect on the ethical precepts that these policies will eventually anchor on. However, in reality, perhaps due to ethical ignorance, "questions like these often remained unanswered and sometimes even unasked, in the formulation and implementation of environmental

Corresponding Author: Ravichandran Moorthy, School of History, Politics and Strategy, Faculty of Social Sciences and Humanities, University Kebangsaan Malaysia, 43000 Bangi, Selangor, Malaysia

Tel: +603-89215825, Fax: +603-89213290 
policies and actions" (Ten Have, 2006). In environmental policy formulation, it is essential that policies are designed with clear direction-one should seek clarity on what to 'sustain' in development and what to 'preserve' in nature and also clear understanding on the extent such initiatives to be undertaken. In general the debate on environmental ethics concerns falls into four broad dimensions; firstly it reflects on human beings' ethical relationship with the natural environment; secondly it concerns human beings' responsibility in safe guarding and preserving natural environment; thirdly it concerns human beings' in providing leadership in safe guarding and preserving natural environment andfourthly it concerns human beings' in ensuring earth's resources remains adequate for future generations. In this light that this study attempts to examine the extent environmental ethics manifest in the management of urban river.

Water is an essential necessity of human existence and industrial development and it is one the most delicate component of the environment (Das and Acharya, 2003; Yisa and Jimoh, 2010; Yu and Salvador, 2005). Rivers supply more than $90 \%$ of water supply- which originate from highland forest and catchments areas. River is source of life, providing freshwater for human consumption, irrigation for agriculture, as a means of transportation, a source of food in fisheries, hydro-electric power and water use for industries. Therefore, monitoring its water quality has become necessary initiative, especially for rivers affected by urban effluents. "Furthermore, the poor quality of water is compounding the problems of scarcity. More than half of the world's lakes and rivers are seriously polluted andhalf the world's wetlands have disappeared in the last century. Water borne diseases are a major cause of death. Seven million people die annually of such diseases" (Llamas, 2009). Studies on water quality in the aquatic environment are still popular in the evaluation and management of rivers ecosystems in many countries (Watts and Smith, 1994; Njenga, 2004; Campbell, 1994; Amadi et al., 2010). Recognizing the importance of 'water' to the existence of life on earth, the discourse on 'water ethics' started to emerge in several international documents on environment in the last several decades. The World Commission on the Ethics of Science and Technology (COMEST) and the International Hydrology Programme (IHP) has significantly highlighted the need for the development of 'water ethics' in the management of water resources. In fact the COMEST committee on water has gone further to identify several core principles to cover aspects such as human dignity, participation, solidarity, equality, common good, stewardship, transparency and universal access to information, inclusiveness and empowerment (Liu et al., 2011). These principles are not a new phenomenon they have been expounded in several other United Nations documents pertaining to bioethics, human rights and the environment.

Like other developing and developed countries, development along the rivers as well as in the hinterland has caused major damage to the health and beauty of rivers in urban areas in Malaysia. Soil erosion caused by land development in the surrounding areas and untreated wastes discharged from nearby factories further contribute to the contamination of rivers. These toxic wastes not only destroy aquatic life and microorganisms but also the surrounding vegetation, flora and fauna due to its highly acidic levels. However, with the powers assigned to agencies involved in river management, it is puzzling as to why the rivers in Malaysia are still threatened by serious pollutants (Chan, 2003). Therefore it is necessary to examine the weakness of various agencies and inter-agency coordination between these agencies to uncover the root causes of poor mitigation of river pollution and remedial measures put in place immediately. There are several agencies involved in the river management, namely the Department of Environment (DOE), Drainage and Irrigation Department (DID) and the local government. Each of these agencies has specific and interrelated function with other agencies.

DID is accountable for (i) drainage and works; (ii) flood improvement works in rural areas and in urban areas at the request of local authorities; (iii) preservation and improvement works of river flow and hydraulic efficiency; (iv) collection and analyzing works of hydrological data for water resources developments and (v) taking on an advisory role to the land office on matters relating to river reserves and to development of river banks. Their main objective is to provide engineering services which are beyond the capability of the target group itself and subsequently to ensure optimum land utilization and more efficient management of the nation's water resources. DOE is responsible for the coordination of all activities related to the discharge of wastes into the environment, prevention and control of pollution and protection and enhancement of the quality of the environment. DOE is also responsible for the monitoring and control of water quality of the river systems. Thus, the main function of DOE is the monitoring and control of discharge of effluents to ensure water quality in the rivers and watercourses conform to the approved limits. The local government, which is under the State office, is another agency involved in river management. The federal 
Am. J. Environ. Sci., 7 (4): 370-376, 2011

government only has direct control over federal territories, namely Kuala Lumpur City Hall, Putrajaya (the new administrative center) and the island of Labuan. Local authority councils generally manage committees made up of councilors and local authority officials and make policies under the full council meeting. The Town and Country Planning Act provides for the powers of local authorities to function as local planning authorities.

Based on the discussion above, this study examines the extent environmental ethics principles manifest in the management of urban river, especially with regards to coordination between agencies involved in river management. To achieve this, the study (i) measure the level of pollution in the Gombak River and (ii) examine inter-agency coordination between river management agencies, namely DOE, DID and Selayang Municipal Council (MPS) on their efforts to manage pollution in the Gombak River. The study has argued that weakness in inter-agency coordination as a result of 'grey-area' in management functions and departmental parochialism are main contributors to river mismanagement, especially with regard to pollution. An ethical framework was employed to analyze the issue. This framework provides for critical thinking on ethical precepts on how to balance different benefits, risk and duties when dealing with environmental issues. Essentially it is not about seeking a singular correct solution to an ethical issue but rather it suggests different choices made after ethical reflections (Macer, 2008; Moorthy et al., 2011; Moorthy and Sivapalan, 2010).

\section{MATERIAL AND METHODS}

Location of study area: This study was conducted in Malaysia, more specifically in the Gombak River which flows through several urban centers in the locality of the capital Kuala Lumpur.

Data collection and analysis: Two modes of data collection were applied in this study. The first is quantitative analysis to assess the river water quality. It is on based on Biochemical Oxygen Demand (BOD) standards (Table 1). BOD is a frequent water quality standards employed to express the content of easily biodegradable organic matter it may come from natural ecosystem or from sewerage or other wastewater. A river has considerable ability to decrease BOD as organic matter, degraded by micro-organisms. However, very high BOD loading, if released into the river, may result in the depletion of oxygen in the river system. This situation may result in serious consequences on the living organisms of river.
Table 1: River classification according to BOD Standards

\begin{tabular}{|c|c|c|}
\hline Class & Suitable usage & BOD \\
\hline $\mathrm{I}$ & $\begin{array}{l}\text { Conservation of the environment. } \\
\text { Water supply: practically no treatment needed. } \\
\text { Suitable for very sensitive aquatic species }\end{array}$ & $<0.1$ \\
\hline II & $\begin{array}{l}\text { Water supply: conventional treatment. } \\
\text { Suitable for sensitive aquatic species and } \\
\text { recreational use with body contact. }\end{array}$ & $1.0-3.0$ \\
\hline III & $\begin{array}{l}\text { Water supply: extensive treatment needed. } \\
\text { Suitable for common and tolerant } \\
\text { fish species and livestock. }\end{array}$ & $3.0-6.0$ \\
\hline IV & Suitable for irrigation only. & $6.0-12.0$ \\
\hline $\mathrm{V}$ & Not suitable for water supply and irrigation. & $>12.0$ \\
\hline
\end{tabular}

(Source: Adapted from MEQR, 2006)

The second source of data is derived through interviews with several key informants from the DID, DOE and MPS and other agencies involved in environmental protection. The interviews solicit respondents' impressions, interpretations and opinions regarding agencies' roles in river management and the issues pertaining to inter-agency coordination.

\section{RESULTS}

The results are discussed based on levels of river pollution and issues relating to inter-agency coordination. The first part shows water quality levels in the Gombak based on samples taken from 5 points along the rivers on 5 consecutive days from 26-30th January 2009. These measurements provide conclusion on the level of river pollution. The second part outlines the responsibilities of various agencies addressing river pollution and the workings of inter-agency cooperation and facilitation mechanism.

In terms of inter-agency mechanism, Table 3 shows the role and responsibility of each agency in Gombak District involved in river water management.

\section{DISCUSSION}

Sampling point's analysis: Point $A$ is at the upstream part of Gombak River. There are not many large scale industries, except some small workshops and few shop houses operating as small scale industries for wood and food processing. There is also a Malay village settlement and fishing activities using fish nets have been observed here. It was observed that the BOD value for Point A ranges between 2.0-3.2 $\mathrm{mg} \mathrm{L}^{-1}$ from 26-30 January 2009 with only $5 \%$ of the value falls into Class III. There is an increase in the BOD value every day after 3.00 p.m. probably is due to a bridge construction project which started in October 2008. Construction activities were noted only after mid-day in each of the day studied. Point B, which is located at downstream is found near a rubbish dumping site and a car repair workshop. 
Am. J. Environ. Sci., 7 (4): 370-376, 2011

Table 2: Sampling Results of Water Quality (26 -30 January 2009)

\begin{tabular}{|c|c|c|c|c|c|c|c|c|c|c|c|}
\hline \multirow[b]{2}{*}{$\begin{array}{l}\text { Point } \\
\text { samples taken }\end{array}$} & \multirow[b]{2}{*}{ Time } & \multicolumn{2}{|c|}{26 January 2009} & \multicolumn{2}{|c|}{27 January 2009} & \multicolumn{2}{|c|}{28 January 2009} & \multicolumn{2}{|c|}{29 January 2009} & \multicolumn{2}{|c|}{30 January 2009} \\
\hline & & $\begin{array}{l}\text { BOD } \\
(\mathrm{mg} / \mathrm{L})\end{array}$ & Class & $\begin{array}{l}\text { BOD } \\
(\mathrm{mg} / \mathrm{L})\end{array}$ & Class & $\begin{array}{l}\text { BOD } \\
(\mathrm{mg} / \mathrm{L})\end{array}$ & Class & $\begin{array}{l}\text { BOD } \\
(\mathrm{mg} / \mathrm{L})\end{array}$ & Class & $\begin{array}{l}\text { BOD } \\
(\mathrm{mg} / \mathrm{L})\end{array}$ & Class \\
\hline \multirow[t]{4}{*}{$\mathrm{A}$} & $9.30 \mathrm{am}$ & 2.64 & II & 2.44 & II & 2.75 & II & 2.53 & II & 2.54 & II \\
\hline & $12.30 \mathrm{pm}$ & 2.92 & II & 2.66 & II & 2.51 & II & 2.62 & II & 2.46 & II \\
\hline & $3.30 \mathrm{pm}$ & 3.17 & III & 2.60 & II & 2.33 & II & 2.69 & II & 2.52 & II \\
\hline & $6.30 \mathrm{pm}$ & 2.55 & II & 3.31 & III & 2.06 & II & 2.68 & II & 2.59 & II \\
\hline \multirow[t]{4}{*}{ B } & $9.30 \mathrm{am}$ & 3.90 & III & 3.72 & III & 3.45 & III & 2.66 & II & 3.93 & III \\
\hline & $12.30 \mathrm{pm}$ & 4.38 & III & 4.63 & III & 3.74 & III & 3.49 & III & 4.17 & III \\
\hline & $3.30 \mathrm{pm}$ & 4.73 & III & 3.97 & III & 4.22 & III & 3.40 & III & 4.36 & III \\
\hline & $6.30 \mathrm{pm}$ & 3.87 & III & 4.07 & III & 3.79 & III & 4.12 & III & 3.70 & III \\
\hline \multirow[t]{4}{*}{$\mathrm{C}$} & $9.30 \mathrm{am}$ & 3.21 & III & 2.95 & II & 2.57 & II & 2.57 & II & 3.44 & III \\
\hline & $12.30 \mathrm{pm}$ & 3.66 & III & 3.19 & III & 2.74 & II & 2.74 & II & 3.01 & III \\
\hline & $3.30 \mathrm{pm}$ & 3.43 & III & 3.16 & III & 3.03 & III & 3.03 & III & 3.75 & III \\
\hline & $6.30 \mathrm{pm}$ & 2.96 & II & 3.45 & III & 3.08 & III & 3.08 & III & 3.11 & III \\
\hline \multirow[t]{4}{*}{$\mathrm{D}$} & $9.30 \mathrm{am}$ & 3.99 & III & 3.48 & III & 3.58 & III & 2.91 & II & 3.72 & III \\
\hline & $12.30 \mathrm{pm}$ & 4.62 & III & 4.02 & III & 3.33 & III & 3.21 & III & 4.08 & III \\
\hline & $3.30 \mathrm{pm}$ & 4.18 & III & 4.28 & III & 3.91 & III & 3.76 & III & 4.13 & III \\
\hline & $6.30 \mathrm{pm}$ & 4.14 & III & 3.93 & III & 3.70 & III & 4.15 & III & 3.98 & III \\
\hline \multirow[t]{4}{*}{ E } & $9.30 \mathrm{am}$ & 4.30 & III & 4.24 & III & 4.58 & III & 3.68 & III & 4.20 & III \\
\hline & $12.30 \mathrm{pm}$ & 4.81 & III & 4.89 & III & 4.74 & III & 4.20 & III & 4.11 & III \\
\hline & $3.30 \mathrm{pm}$ & 4.15 & III & 4.20 & III & 4.01 & III & 3.74 & III & 3.69 & III \\
\hline & $6.30 \mathrm{pm}$ & 4.78 & III & 4.11 & III & 4.29 & III & 4.22 & III & 4.34 & III \\
\hline
\end{tabular}

Higher depth and lower velocity of the river was observed here. Higher range of $\mathrm{BOD}$ value was registered, ranging from $2.6-4.8 \mathrm{mg} \mathrm{L}^{-1}$ during the study period. Based on the figures in Table 2, the reading appears to be highest around 4.00 p.m. However, only one reading on 28 January 2009 was recorded below $3.0 \mathrm{mg} \mathrm{L}^{-1}$, in particular due to a heavy downpour earlier in the morning. Hence, $95 \%$ of the readings fall into Class III. Compared with Point $\mathrm{A}$, the observations at Point $\mathrm{B}$ are higher. Point $\mathrm{C}$ which is located at the downstream part of Gombak River was found to be active with industrial activities such as automotive, metal engineering and concrete engineering and surrounded by a large housing estate. There were construction activities in the nearby areas. The BOD value for Point $\mathrm{C}$ was found to be in the range of 2.5$3.8 \mathrm{mg} \mathrm{L}^{-1}$ during the period of field test with $75 \%$ of the BOD value falls into Class III. The drop in the value on the 28th January 2008 was probably caused by heavy downpour in the morning.

Point D, the fourth sampling point is located near a bridge. Several shop houses were seen operating motorcycle and car workshops. Some housing projects were being actively developed in this locality. This part of the river is wide. The high content of silt and clay were observed here could be contributed by the accumulative eroded materials from the existing land use development. BOD levels deteriorated at this point ranging from $2.9-4.7 \mathrm{mg} \mathrm{L}^{-1}$, which only $5 \%$ of BOD value falls into Class II. This could be due to the upstream erosion and transport of sediments and silts. The activities also seem to slow down by late evening. The higher value of BOD could perhaps be contributed by two main reasons, i.e., local activities and also pollution from Point B and C. Point E is located near a major settlement and squatter area. There were numerous domestic wastes found in this part of the river, largely generated by squatter settlements and poultry activities. The water is polluted with traces of domestic waste as bubbles could be observed at the surface of the river. High BOD levels were observed at this Point, with all reading falling into Class III indicating a good deal of high oxygen demanding organic matter being present to be decomposed due to the discharge from squatter area. Discharge of high oxygen demanding organic substances in the lower reaches of the Gombak River could deteriorate river water quality and threaten aquatic life and other water uses.

Inter-agency coordination: Coordination between agencies involed in river management has been cited as one of the reasons for river pollution and mismanagement. The arguments presented here are based the analysis of scholarly articles on river management and through feedback from interviews by officials involved in river management initiatives. The paper argues that an effective management of water resources requires full participation from the various stakeholders and carried out in a holistic approach. River pollution involves various cross-cutting interrelated issues that warrants for effective control and management of river pollution. The study shows that the lack of inter-agency coordination in the management of river pollution in Gombak River has been said o have contributed to poor river management. 
Am. J. Environ. Sci., 7 (4): 370-376, 2011

Table 3: Role and responsibility of agencies in Gombak

\begin{tabular}{lll}
\hline Function & Department/Agency & Role \\
\hline Water Supply & DID & $\begin{array}{l}\text { Irrigation water source development. Monitoring stream } \\
\text { flow and irrigation water supply }\end{array}$ \\
& Waterworks Department & Water supply source works. Treatment and supply of drinking water \\
& Tenaga Nasional Berhad (TNB) & Hydropower source works development. Use of water for hydropower \\
(National Power Company) & \\
Water Pollution Control & DOE & Control of industrial pollutions. \\
& MPS/Indah Water Consortium & Control and treatment of sewage. \\
& DID & Control of pollution from irrigation areas. \\
& Mines Department & Control of pollutants from mining operations. \\
Water Quality Management & DOE & Monitoring of water quality \\
& Fisheries Department & Prohibition of use of poisoning or destructive methods for fishing. \\
& Chemistry Department & Analytical services on water samples monitored. \\
& DID & Planning, construction and maintenance of drainage works. \\
Watershed Management & Forestry Department & Protection of forests. Watershed management within forest reserves. \\
& Town and Country & Land use planning and control \\
& Planning Department & \\
& TNB/Waterworks Department/DID & Protection of watershed upstream of reservoirs \\
\hline
\end{tabular}

Usually, these issues are managed on sectoral basis that sometimes give rise to numerous red-tape and departmental rivalry. Given that river management issues are multifaceted and interconnected, there is greater realization on the need to institute a comprehensive river water management system. In Malaysia, water resources laws and the enforcement agencies function within the constitutional framework. Water resource comes under the state government list of control. Water activities such as watershed management, water resources development and management, navigation, fisheries and mining are placed in this list. Despite the comprehensive legislation frameworks at state levels such as the Water Authority Management Enactment in Selangor, there is still a lack of provision that recognizes the role of local communities into water resources planning and management, for example in the Gombak District. As illustrated in Table 3, there are several agencies involved in the management of Gombak River in the Gombak District. For better coordination of interagency coordination, the Ministry of Natural Resources (NRE) was established in 2004, combining departments from four other ministries to ensure better integration of water resources management. While such initiative appears good on paper, the management of water resources was still shared by other ministries such as water services monitoring and supervision (Ministry of Water, Energy and Communication); monitoring and safeguarding of water resources and natural resources (Ministry of Natural Resources and Environment); water research and development (Ministry Science, Technology and Innovation), drinking water quality (Ministry of Health), water planning and development (Local Governments). Although the ministry changed its name to Ministry of Energy, Green Technology and Water from 9 April 2009, the water management efforts were largely segregated between several agencies.
The lack of inter-agency coordination also manifest in the scope of jurisdiction among agencies responsible for natural resources management. For instance, DOE, which executes the Environmental Quality Assessment (EQA) 1974, is responsible for industrial pollution control. The other natural resource sectors like forestry, fisheries, mining and agriculture come under the jurisdiction of other ministries, with split sets of regulatory laws. Each ministry places more importance in promoting polices that they are entrusted with, within their own jurisdictions. However, such actions are done without necessary coordination with related agencies an action that may perhaps more damaging to the environment. In another word, ministries appeared to be overly protective of their powers and jurisdiction of responsibilities. In the case of DOE, it appraises the Environmental Impact Assessment (EIA) report for land development projects and makes recommendations as to whether the development is to be permitted or refused. A planning authority may consult any authority, department, person or body before determining an application for planning permission. Nevertheless, it is not obligatory for the planning authority to strictly follow the recommendations by authorities providing advisory decisions. The planning authority can disregard the recommendations of DOE and other government agencies. The Town and Country Planning Act 1976 provides that in determining planning applications, the planning authorities are required to take into consideration all aspects necessary for proper planning, including the directives given by the State Planning Committee. The State Planning Committee may ask for the approval of an application for planning permission to be considered for the purposes of economic development even if such projects overlap with the policies in the development plans. 
Pollution mitigation and water quality improvement are largely dependent on the efforts of three main agencies, i.e., DID, DOE and MPS. However, integrated involvement from the other agencies is critical to ensure the successful implementation of any proposed reforms in river management. DID's role is to put in place the technology to treat effluents flowing into rivers at strategic points along the rivers. The DOE controls pollution from industrial areas and wastewater treatment plants. The role of MPS is to strengthen its capacity to enforce existing regulations in respect of control of effluents discharged into rivers as well as monitoring earthworks that may cause pollution in rivers. Since there are numerous laws with gaps and overlaps and there are also many agencies and departments involved in dealing with fragmented sectoral functions as such the enforcement has become ineffective and inefficient. There were cases where agencies were entrusted with specific responsibilities but depended on other agencies to enforce the relevant laws. Such circumstances warrant for close cooperation with other agencies, but more often than not, closer coordination is hampered by different priorities and accountabilities. For example, the MPS relied on the advice of the DID for land development control and technical matters. DID have also often taken up the initiatives to prepare drainage master-plans on behalf of the MPS as these authorities in many cases do not have sufficient budget. In addition to the above, due its better financial and technical expertise, they DID also undertake the responsibility of the development of some trunk drains. At present there is no clear guideline to delineate such responsibilities between MPS and DID. As such specific references have to be made to both the DID and the MPS to determine areas of jurisdiction on the ground.

\section{CONCLUSION}

Feedback from the interviews suggested that officers involved in the river water management were less aware of the water ethics. Many of them had shown tendencies to approach water issues from a technical perspective; they were less cognizant to the socioeconomic and social justice perspectives of river water management. Water ethics awareness among stakeholders, implementers and enforces is still significantly lacking. Most water managers and individuals involved in river water management appeared to favor only technical and scientific solutions to water issues. Even though there are many legislations and guidance, there exists a gap in the implementation of action plans which needs to be addressed. Enforcement was found to be lacking and the authorities appear to be pointing fingers at each other whenever problem arises. Therefore, it may be necessary that a sole agency that has a legal backing is entrusted with the responsibility to control river water pollution. As water issues influence the bigger societal dynamics, it is imperative to inculcate an ethical grounding on how to approach river water management holistically taking into consideration elements of human dignity, society participation and responsibility, equality, common good, stewardship and other precepts that will assist in the preservation of the rivers and its ecosystems for the continued use of future generations.

\section{REFERENCES}

Amadi, A.N., P.I. Olasehinde, E.A. Okosun and J. Yisa, 2010. Assessment of the water quality index of otamiri and oramiriukwa rivers. Physics Int., 1: 116-123. DOI: 10.3844/pisp.2010.116.123

Campbell, K.R., 1994. Concentrations of heavy Metals associated with urban runoff in fish living in stormwater treatment ponds. Arch. Environ. Contamin. Toxicol., 27: 352-356. DOI: 10.1007/BF00213171

Chan, N.W., 2003. Water Resources Management in Malaysia: NGO Perspectives.

Das, J. and B.C. Acharya, 2003. Hydrology and assessment of lotic water quality in Cuttack city, India. Water, Air, Soil Pollut., 150: 163-175. DOI: 10.1023/A:1026193514875

Liu, J., A. Dorjderem, J. Fu, X. Lei and H. Liu et al., 2011. Water Ethics and Water Resource Management. Ethics and Climate Change in Asia and the Pacific (ECCAP) Project Working Group 14 Report. UNESCO Bangkok.

Llamas, M.R., 2009. Water Ethics: Marcelino Botin Water Forum 2007. 1st Edn., Taylor and Francis Group, London, UK: CRC Press, ISBN: 9780415473033, pp: 353.

Macer, D.R.J., 2008. Moral Games for Teaching Bioethics. UNESCO Chair in Bioethics, Israel. http://www.eubios.info/MacerMoralGames.pdf

MEQR, 2006. Department of Environment, Ministry of Natural Resources and Environment Malaysia

Moorthy, R. and S. Sivapalan, 2010. Some ethical thoughts from the Indian traditions. Eubios, J. Asian, Int. Bioethics, 20: 180-183.

Moorthy, R., E.A. Choy, S. Selvadurai and N. Lyndon, 2011. Bioethics principles in the teaching of climate change. Am. J. Applied Sci., 8: 962-966, DOI: 10.3844/ajassp.2011.962.966 
Njenga, J.W., 2004. Comparative studies of water chemistry of four tropical lakes in Kenya and India. Asian J. Water, Environ. Pollut., 1: 87-97.

Ten Have, H.A.M.J., 2006. Environmental Ethics and International Policy. 1st Edn., UNESCO, Paris, ISBN: 9789231040399, pp: 226.

Watts, S.E.J. and B.J. Smith, 1994. The contribution of highway run-off to river sediments and implications for the impounding of urban estuaries: A case study of Belfast. Sci. Total Environ., 146: 507-514. DOI: 10.1016/0048-9697(94)90276-3
Yisa, J. and T. Jimoh, 2010. Analytical studies on water quality index of river landzu. Am. J. Applied Sci., 7: 453-458. DOI: 10.3844/ajassp.2010.453.458

$\mathrm{Yu}$, L. and N.N.B. Salvador, 2005. Modelling water quality in rivers. Am. J. Applied Sci., 2: 881-886. DOI: 10.3844/ajassp.2005.881.886 